Portland State University

PDXScholar

6-2021

\title{
Inter- and intracontinental Migration by the Eastern Kingbird (Tyrannus tyrannus)
}

\author{
Daniel H. Kim \\ Platte River Whooping Crane Maintenance Trust \\ Lucas J. Redmond \\ Portland State University \\ James R. Fox \\ British Antarctic Survey \\ Michael T. Murphy \\ Portland State University, murphym@pdx.edu
}

Follow this and additional works at: https://pdxscholar.library.pdx.edu/bio_fac

Part of the Biology Commons, and the Ornithology Commons

Let us know how access to this document benefits you.

\section{Citation Details}

Kim, D. H., Redmond, L. J., Fox, J. R., \& Murphy, M. T. (2021). Inter-and intracontinental migration by the Eastern Kingbird (Tyrannus tyrannus). The Wilson Journal of Ornithology, 133(2), 202-214.

This Article is brought to you for free and open access. It has been accepted for inclusion in Biology Faculty Publications and Presentations by an authorized administrator of PDXScholar. Please contact us if we can make this document more accessible: pdxscholar@pdx.edu. 


\title{
Inter- and intracontinental migration by the Eastern Kingbird (Tyrannus tyrannus)
}

\author{
Daniel H. Kim, ${ }^{1,5 *}$ Lucas J. Redmond, ${ }^{2}$ James R. Fox, ${ }^{3}$ and Michael T. Murphy ${ }^{4}$
}

ABSTRACT - We recovered 12 archival geolocators deployed on Eastern Kingbirds (Tyrannus tyrannus) breeding in New York (NY; $n=3,2$ with 2 years of data), Nebraska (NE; $n=6,1$ with 2 years of data), and Oregon (OR; $n=3)$ to describe migratory routes, timing and rates of migration, nonbreeding season distributions, and migratory connectedness. NY fall migrants migrated along the Atlantic coast to Florida, flew either nonstop across the Gulf of Mexico (GoM; 2 of 3 birds) or stopped once along the way (Cuba and Cayman Islands in different years) to land in Yucatan/Central America. Fall birds from NE and OR arrived at the GoM in the region of the border between Texas and Louisiana, and most likely took a land route to Central America. In spring, all NY birds flew nonstop across the GoM, and once in North America, took a more inland route than in fall. Trans-GoM flights were more common among NE and OR birds in spring than fall. Birds migrated faster in spring than fall, and in both seasons, late departure was associated with more rapid migration. Migratory connectivity was low, and all birds from OR, and one bird from NE and NY each, occupied a single region in northwestern Amazonia (southern Colombia, northern Peru, and eastern Ecuador) while in South America. Most kingbirds from NE and NY were intratropical migrants, occupying 2 regions for periods of $\geq 30 \mathrm{~d}$. The latter birds migrated farther south to western Brazil and northern Bolivia, but then moved north to later use the same area in northwestern Amazonia where other birds remained throughout the overwinter period. Northwestern Amazonia thus appears to be a critical area for all Eastern Kingbirds during the nonbreeding season, possibly because a prolonged wet season supports abundant fruit resources. Received 24 September 2019. Accepted 22 July 2021.

Key words: archival geolocator, departure date, intratropical migration, migration rate, migratory connectivity.

\section{Migración inter- e intracontinental del mosquero Tyrannus tyrannus}

RESUMEN (Spanish) - Recuperamos 12 geolocalizadores que habíamos puesto en mosqueros Tyrannus tyrannus que anidaban en New York (NY; $\mathrm{n}=3,2$ con 2 años de datos), Nebraska (NE; $\mathrm{n}=6,1$ con 2 años de datos) y Oregon (OR; $\mathrm{n}=3$ ) para describir sus rutas migratorias, temporalidad y tasas de migración, distribuciones durante la temporada no-reproductiva y conectividad migratoria. En otoño, los de NY migraron a lo largo de la costa del Atlántico a Florida, volaron sin parar el cruce del Golfo de México (GoM; 2 de 3 pájaros) o hicieron una parada en el camino (Cuba e Islas Caimán en años diferentes) para aterrizar en la península de Yucatán/Centroamérica. En otoño, los pájaros de NE y OR llegaron al GoM en la región limítrofe entre Texas y Louisiana, y lo más probable es que hayan tomado una ruta de tierra firme a Centroamérica. En primavera, todos los pájaros de NY cruzaron el GoM sin parar y una vez en Norteamérica tomaron una ruta más tierra adentro que en otoño. Los vuelos trans-GoM fueron más comunes entre los pájaros de NE y OR en primavera que en otoño. Estos pájaros migraron más rápido en primavera que en otoño; en ambas temporadas, una partida tardía estuvo asociada con una migración más rápida. La conectividad migratoria fue baja y todos los pájaros de OR, uno de NE y uno de NY ocuparon una región única de la Amazonia noroccidental (sur de Colombia, norte de Perú y el este de Ecuador) mientras permanecieron en Sudamérica. La mayoría de los mosqueros de NE y NY fueron migratorias intratropicales que ocuparon 2 regiones por periodos de $\geq 30 \mathrm{~d}$. Éstos últimos migraron más al sur al occidente de Brasil y al norte de Bolivia, pero después se movieron al norte para utilizar la misma área en la Amazonía noroccidental donde el resto de los individuos permanecieron a lo largo del periodo no-reproductivo. La Amazonía noroccidental parece ser un área crítica para todos los $T$. tyrannus durante la temporada no-reproductiva, posiblemente porque su prolongada estación húmeda da soporte a abundantes frutos.

Palabras clave: conectividad migratoria, fecha de partida, geolocalizadores, migración intratropical, tasa de migración.

Events outside the breeding season account for up to three-quarters of the annual cycle of Nearctic-Neotropical songbirds, yet basic information on wintering site locations, migratory pathways, connectivity of populations, and movements during the overwintering period remain

\footnotetext{
${ }^{1}$ Platte River Whooping Crane Maintenance Trust, Wood River, NE, USA

${ }^{2}$ Penn State Schuylkill, Schuylkill Haven, PA, USA

${ }^{3}$ British Antarctic Survey, National Environmental Council, High Cross, Cambridge, UK

${ }^{4}$ Department of Biology, Portland State University, Portland, OR, USA

${ }^{5}$ Current address: USFWS South Dakota Field Station, Pierre, SD, USA

* Corresponding author: daniel_kim@fws.gov
}

poorly known for most species (Faaborg et al. 2010).

The use of archival light-level geolocators over the past decade has begun to shed light on this allimportant period of the annual cycle. For instance, Ovenbirds (Seiurus aurocapilla; Hallworth et al. 2015) and Golden-winged Warblers (Vermivora chrysoptera; Kramer et al. 2017) exhibit strong migratory connectivity while others such as Bobolinks (Dolichonyx oryzivorus; Renfrew et al. 2013) and Purple Martins (Progne subis; Stutchbury et al. 2016) do not. Patterns of intratropical movement during the overwintering period also differ considerably, and in some, intratropical migration (ITM) seems obligatory (Veery [Catharus fuscescens]; Heckscher et al. 2011) whereas in others it is 
facultative (Purple Martin, Stutchbury et al. 2016; Great Reed Warblers [Acrocephalus arundinaceus], Koleĉek et al. 2018). Data on more species are needed to answer why such variability exists.

Eastern Kingbirds (Tyrannus tyrannus) breed over much of southern Canada and the United States and undertake one of the longest migratory flights of all Nearctic-Neotropical migrants (see Pollack-Velásquez et al. 2020). Knowledge of the Eastern Kingbird's nonbreeding range is sparse (but see Jahn et al. 2013a, MacPherson et al. 2018, Pollack-Velásquez et al. 2020). Here, we reexamine geolocator data collected from birds breeding near the center of the Eastern Kingbird range in Nebraska (NE) and reported on in Jahn et al. (2013a) using more recent analytical methods. We also add new geolocator data on Eastern Kingbird migration collected from populations from the far eastern (New York; NY) and far western (Oregon; OR) portions of their range. Our goals were to establish migratory schedules and paths, migratory rates, and identify potential stopover locations and wintering sites. We were especially interested in establishing whether Jahn et al.'s (2013a) report of ITM was exhibited by all populations of kingbirds. Given their apparent reliance on shifting distribution of primary productivity in South America (MacPherson et al. 2018), and flocking and frugivorous behavior in the nonbreeding season (Murphy and Pyle 2018), we expected, a priori, low levels of connectivity. We also expected, given delayed breeding in OR compared to the virtually identical and earlier breeding of Eastern Kingbirds from NY and NE (MTM and DHK, unpubl. data), either a delayed departure from South America or slower rate of spring migration by OR birds, and a delayed departure date in late summer compared to NY and NE. Finally, given heavy use of the Atlantic coast region by migrant passerines in the fall (La Sorte et al. 2014), we predicted migration through Florida and trans-Gulf of Mexico (GoM) flights for NY kingbirds, but that birds farther west in NE and OR would more often avoid GoM flights in favor of overland flights that hugged the east coast of Mexico.

\section{Methods}

During the breeding season, we used mist nets to capture Eastern Kingbirds at long-term study areas at Malheur National Wildlife Refuge in southeastern Oregon $\left(2009 ; 42^{\circ} 49^{\prime} \mathrm{N}, 118^{\circ} 54^{\prime} \mathrm{W}\right)$, the Platte River Whooping Crane Maintenance Trust in south-central Nebraska $\left(2010 ; 40^{\circ} 48^{\prime} \mathrm{N}\right.$, $98^{\circ} 26^{\prime} \mathrm{W}$ ), and in privately owned rural habitats in central New York $\left(2012 ; 42^{\circ} 28^{\prime} \mathrm{N}, 75^{\circ} 04^{\prime} \mathrm{W}\right)$. We weighed, measured, and fitted birds with an individually numbered USGS band and a unique combination of 3 plastic color bands. All birds in our study were AHY and male (based on presence of cloacal protuberance) with one exception (a female, based on brood patch). Archival light-level geolocator units were then attached (model Mk10s $1.2 \mathrm{~g}$ British Antarctic Survey, Cambridge, UK, or model P65 0.75 g Migrate Technology, Cambridge, UK) to 10,10 , and 9 kingbirds, respectively, in OR, NE, and NY using a Rappole-Tipton leg-loop Harness (Rappole and Tipton 1991) and size 600 Kevlar thread (Ryder et al. 2011). All individuals weighed at least $35 \mathrm{~g}$ (most were between 38 and $42 \mathrm{~g}$, and therefore geolocator and harness represented a maximum of $4.3 \%$ of body mass.

The NE bird data were used previously in a multi-species paper by Jahn et al. (2013a). However, those data were analyzed using only day length and local noon data using BAStrack software (British Antarctic Survey). We used TAGS, an online interface to visually inspect data and generate morning and evening twilight vectors for each day of data recorded (http://tags. animalmigration.org). We used a twilight threshold of 5.0 for the Mk10 units and 0.9 for the P65 units. Our examination of the data suggested that shading, possibly due to either communal roosting or topography prior to spring migration, affected sunrise/sunset estimates from approximately 15 February to the end of March.

For our analysis we used twilight data analyzed by FLightR package 3.7 (Rakhimberdiev et al. 2015) in R 3.2.4 (R Core Team 2017). FLightR uses a hidden Markov-chain model over the entire temporal period and spatial extent to reconstruct a probability distribution for bird location, probable migratory path, and wintering areas (Rakhimberdiev et al. 2015, 2017). We used recommended default values to determine movements by individuals, that is, mean distance moved of $300 \mathrm{~km}$ with $500 \mathrm{~km} \mathrm{SD}$ (Rakhimberdiev et al. 2017). We omitted outliers with Tsoutliers (R package, see Rakhimberdiev et al. 2015). FLightR produces 
both median and mean estimated positions for each twilight; like Renfrew et al. (2019), median positions produced fewer sedentary locations over the ocean. As our geographic distribution mirrors that of Bobolinks from Renfrew et al. (2019), we followed their settings of $100 \mathrm{~km}$ distance for node length for FLightR, including the use of land mask and the associated credibility intervals (CIs) as a measure of uncertainty (Rakhimberdiev et al. 2017). We calibrated geolocators using on-bird data from the first $10-25 \mathrm{~d}$ post-deployment. These data accurately represented breeding areas in the season of deployment and again prior to recapture the following year.

The potential shading problem during late winter was more extreme for the MK10 model (OR and NE birds) than the P65 model (NY birds) due to the longer interval between light records ( 5 vs. $2 \mathrm{~min}$ ). We therefore excluded wintering points for all NE and OR birds from this period (15 Feb31 Mar). General migratory paths of the OR and NE birds in spring conformed to the shape of Central America (Fig. 1), but error estimates were near their maxima during both spring and fall migration and the majority of point estimates had error ellipses that encompassed a land-based migratory pathway for birds from OR and NE during fall, but not spring.

To illustrate the locations of individuals during migration, we used ArcMap 10.4.1 (ESRI 2016). Due to the smaller credibility intervals associated with the NY population, we estimated fixed kernel densities using the spatial analyst tool in ArcMap 10.4.1 (ESRI 2016) based on point locations for all NY individuals for both fall and spring migration. We include areas with multiple consecutive points with the same latitude and longitude to illustrate potentially important migratory stopover locations. We present kernel densities encompassing 50\%, $75 \%$, and $90 \%$ of the maximum density. To illustrate migration paths for all birds we used the points to line feature using the data management tool in ArcMap 10.4.1 (ESRI 2016).

\section{Criteria for determining migratory timing and distances covered}

We used sustained movements of over $100 \mathrm{~km}$ in longitude with no reversals to mark the onset of fall and spring migration. While in North America in both fall and spring, individual birds occurred at

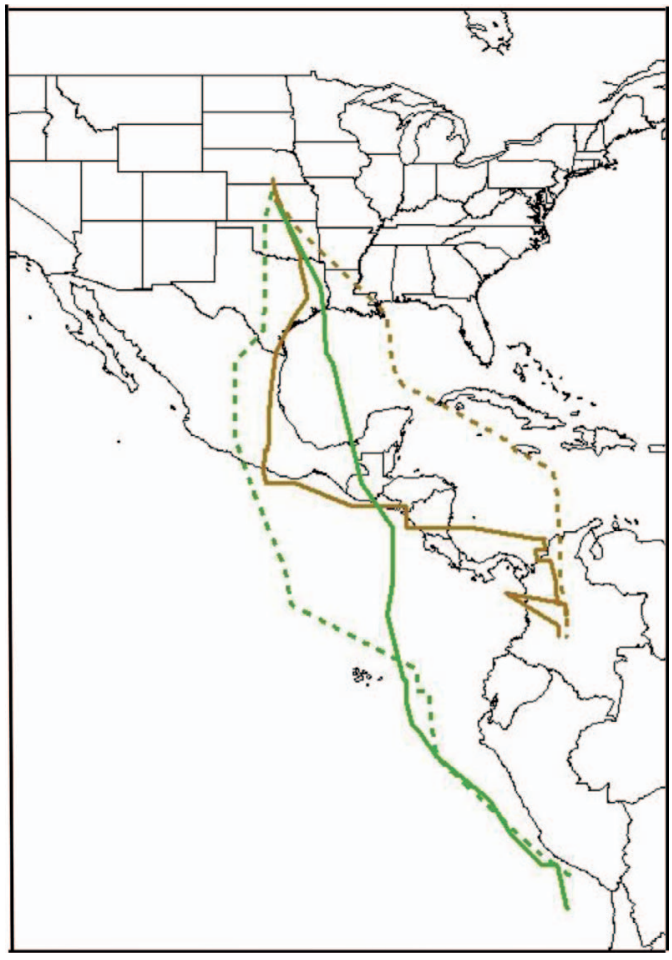

Figure 1. Migratory paths of a single Eastern Kingbird between its breeding location in Nebraska and Central/South America over the course of 2 consecutive years. Dashed and solid lines are fall and spring flights, respectively. Green lines are for the first year and umber lines are for the second. Migratory paths for the first year that were located over the Pacific Ocean were not reliable, but importantly, credibility intervals for the first fall flight overlaps land while that of the second did not, placing the second fall flight over the Gulf of Mexico. Credibility intervals of the spring flights also placed the first spring flight over the Gulf of Mexico, but over land for the second.

appropriate longitudes for their breeding sites, but at latitudes south of those same sites, suggesting some birds may have initiated fall migration with a southern movement or may have arrived in spring prior to actual reported spring return dates due to geolocation error.

During fall migration, we estimated migratory distances for birds at each study site based on the potential for overland routes (from OR and NE) and/or a route crossing the GoM from Texas (for OR and NE birds) or Florida (for NY birds). GoM crossings for OR and NE birds appeared to start in Texas and end in the Yucatan Peninsula, while NY birds appeared to start in the lower half of Florida 
and end farther south in Central America. The remainder of the trip was calculated based on straight lines from Central America to Medellín, Colombia, then to the central point of their first wintering area clusters. We chose Medellín as it is close to the Isthmus of Panama and is situated within a saddle where 2 mountain ranges meet. As all birds fly to the east side of the Andes (contra Hilty and Brown 1986), this seemed the most likely route for birds leaving coastal South America. All distances were calculated as straight-line flights, therefore they represent conservative estimates of actual movements. Likewise, average daily migration speeds are conservative as they include time spent at potential stopover areas prior to settlement at the initial wintering areas (i.e., locales without major movement for $30+d)$. We identified the initiation of ITM through movements of over $200 \mathrm{~km}$ with no reversals occurring after $30 \mathrm{~d}$ of established residency after 1 November.

In spring, our criteria for initiation of migration were a sustained western movement $>100 \mathrm{~km}$ with no reversals. To establish spring migration distances, we assumed migrants from all regions performed a series of straight-line flights starting at Medellín, Colombia. The first leg comprised a flight to Jalapa, Guatemala. For OR and NE birds, we then assumed flights occurred between Jalapa straight to Merida in the Yucatan, and then to Port Lavaca, Texas, ending with a straight-line flight to the study sites. For NY birds we assumed that birds flew from Jalapa, Guatemala, to Cancún, Mexico, to Cedar Key, Florida, and then terminated in Oneonta, NY. These routes provide reasonable and conservative distances to estimate mean migratory speeds over the respective spring and fall migrations.

\section{Statistical analyses}

We compared behaviors between fall and spring migration seasons using $t$-tests and among populations using analysis of variance (ANOVA). To explore potential relationships among migratory behaviors we combined data across sites and used least squares linear regression, along with analysis of covariance (ANCOVA) with site as a fixed factor. All analyses were conducted with STATISTIX 9.0 (Analytical Software, Tallahassee, Florida, USA), and statistics are given as mean $\pm \mathrm{SE}$, and $n$. Results are reported as significant $(P \leq 0.05)$, marginally nonsignificant $(0.10 \geq P>0.05)$, or nonsignificant $(P>0.10)$.

\section{Results}

In the year following deployment, we observed 4,8 , and 5 of the 10, 10, and 9 birds from OR, NE, and NY (total $=29$ ), respectively, that had been fitted with geolocators. Minimum return rate was thus $59 \%$ (17 of 29 birds), which did not differ from Cormack-Jolly-Seber estimates of annual survival for kingbirds from either OR $(64.9 \%$, 95\% CI $=56.0-72.8 \%$; Redmond and Murphy 2012) or kingbirds from NY that bred in optimal habitats $(69.4 \%, 95 \% \mathrm{CI}=58.6-80.0 \%$; Murphy 2001). Of the 17 resighted birds, we recaptured only 3,6 , and 1 of the OR, NE, and NY birds, respectively, in the year following deployment, but in the second year after deployment we recaptured 1 and 2 of the NE and NY birds, respectively, that we did not recapture in the previous year. Thus, geolocators were recovered from a total of 13 birds, but only 12 yielded usable data (one NE geolocator failed to collect usable data). The geolocator from the NE bird recovered in the second year yielded 2 full years of migratory data, while geolocators from the NY kingbirds recaptured in the second year provided at least 20 months of data. On-bird calibrations of geolocators using noon estimations closely approximated breeding season locations; on average, birds were placed within $89 \pm 15 \mathrm{~km}$ and $29 \pm 10 \mathrm{~km}$, respectively, of actual breeding location latitude and longitude.

\section{Fall migration}

NY and OR birds left the breeding grounds by early to mid-August, while NE birds departed by mid- to late August (Table 1). After initial departure, NY birds spent 8-20 d in the midAtlantic region about $300 \mathrm{~km}$ south of the breeding area (Fig. 2A, B, C). All birds then undertook a single nonstop flight $\geq 1,000 \mathrm{~km}$ to Florida where they arrived by the end of the first week of September (Fig. 2A, B, C). Seven to 14 more days were spent either stationary or moving minimally $(<100 \mathrm{~km})$ before departing to cross the GoM. Two birds flew nonstop to Honduras (Fig. 2A, C), 


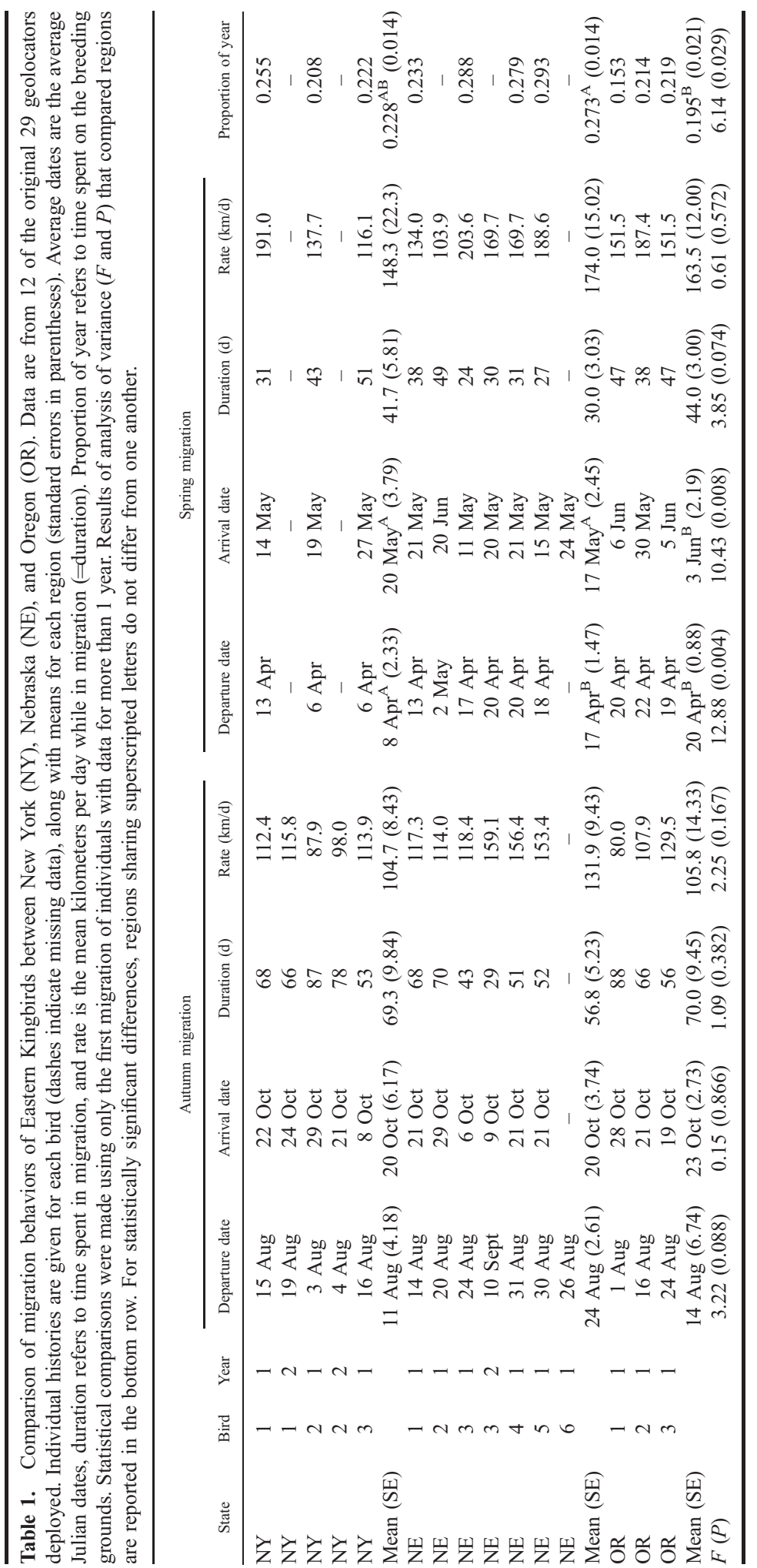



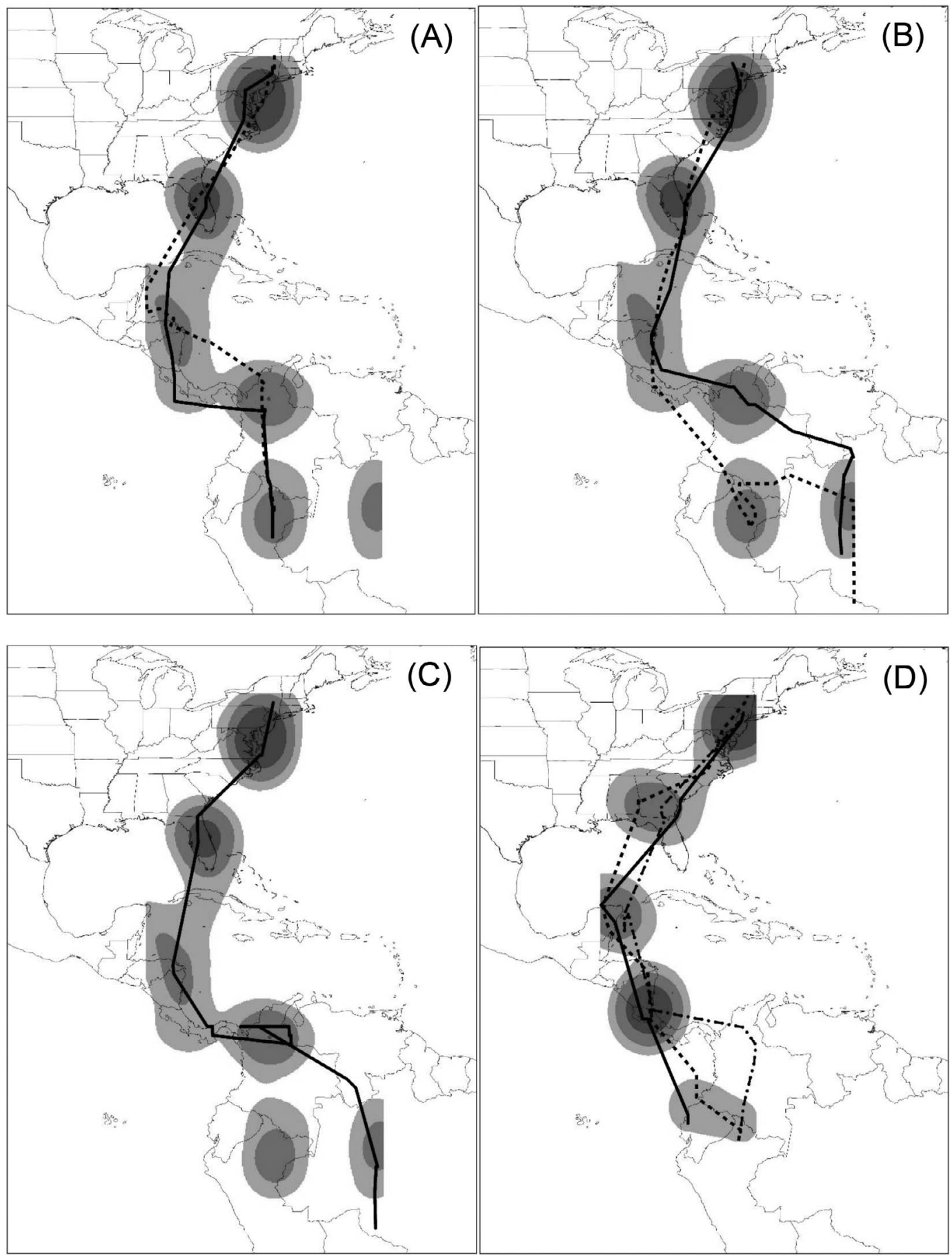

Figure 2. Migratory routes of Eastern Kingbirds between central New York and South America for fall (A-C) and spring (D). One year of data were available for all 3 individuals and each line represents an individual. Fall routes shown individually in A, B, and C, with first flights represented by a solid line and second flight with dashed lines. Shaded zones are $50 \%, 75 \%$, and $90 \%$ kernel estimates of maximum density based on locations for all 3 individuals, whereas unshaded areas with lines represent regions through which the birds migrated without stopping. 
while the third bird stopped for $6 \mathrm{~d}$ in the Cayman Islands before also arriving in Honduras (Fig. 2B).

Closer proximity of migration dates to the fall equinox and the longer interval between light records for NE and OR birds prevented us from extracting maps of migratory routes as detailed as that for NY birds. However, none of the NE or OR birds undertook a long flight in North America such as that shown by the NY birds. NE birds flew directly south to the coast of Texas $(n=4)$ or Louisiana $(n=2)$, while 2 of the 3 OR birds appeared to move east-southeast to the Great Salt Lake, south to the Colorado River, and then east to New Mexico until finally arriving at the GoM in the region of the Texas-Louisiana border. The third bird took a more circuitous route but ultimately arrived in the same area. Recovery of an Eastern Kingbird in Louisiana in September 2007 that was banded by us in OR in July 2007 (D. Bystrak pers. comm.) is consistent with our geolocator findings.

Based on credibility intervals intersecting land within Central America, FLightR estimates suggested most birds from NE and OR took a land route along the east coast of Mexico to Central America. The 2 exceptions appeared to cross the GoM to the Yucatan Peninsula. Departure dates for NE birds that took land routes $(28$ Aug $\pm 3.3 \mathrm{~d}, n$ $=4$ ) were marginally earlier than the 2 birds that crossed the GoM (8 and 9 Sep, 1 -sample $t$-test $=$ 3.03, $P=0.056$ and $t=3.32, P=0.045$, respectively, $\mathrm{df}=3$ for both). Despite different migratory paths, birds from the 3 regions reached their initial wintering areas, on average, within $3 \mathrm{~d}$ of each other at the end of the third week of October (Table 1). Neither number of days in transit nor rate of migration differed among regions (Table 1), and birds migrated an average of $118 \pm 7.7 \mathrm{~km} / \mathrm{d}(n=11)$.

\section{Spring migration}

Geolocators of the 2 NY birds with 2 years of data failed to record after February of the second year. Other than spring departure and arrival date and migratory path (over water or land), $1 \mathrm{NE}$ bird did not yield usable spring data. Another NE bird inexplicably flew to Georgia before finally rerouting to arrive in Nebraska by 20 June (also noted by Jahn et al. 2013a). Excluding the latter individual from spring arrival date, we had 3, 4, and 3 records for NY, NE, and OR, respectively, and a fifth record for NE birds for routes taken when confronted with the GoM but for whom duration of migration could not be determined.

Nine of 10 birds embarked on a land-based spring migration through Central America. The exception was the NY bird that completed a 750 $\mathrm{km}$ flight over the Pacific Ocean between the coasts of Ecuador and Panama (Fig. 2D). Credibility intervals for a second NY bird that appeared to cross the Pacific Ocean (Fig. 2D) could not rule out a land route. NY birds then moved to the Yucatan to make nonstop overwater flights to Florida between 27 and 30 April; landfall occurred in the vicinity of the Florida Panhandle (Fig. 2D). Once in North America, spring migrant flights of NY birds covered shorter distances and were more numerous; from Florida it took $20 \pm 2.0 \mathrm{~d}(n=3)$ to return to NY. After traversing Central America, 5 of 6 NE birds appeared to also fly over the GoM to make landfall on the Texas/Louisiana coast by 30 April $\pm 2.4 \mathrm{~d}(n=4$; date of fifth bird uncertain). One individual took only $4-6 \mathrm{~d}$ to return to NE from the coast, but the mean was 15 $\pm 5.5 \mathrm{~d}(n=4)$. Resolution of migratory paths of OR birds was poor, but one appeared to take a land route and another flew over the GoM (path of third bird unresolved). The upper CIs of the spring route for OR birds in North America mirrored the fall route for the 2 birds that took the southeastern route and the single bird that took the more northern route in fall. Spring migration routes thus appeared to reverse the fall migration path.

Despite a significantly later departure, NE birds arrived slightly (but not significantly) earlier than NY birds, and both arrived significantly earlier than OR birds (Table 1). Total transit time in spring was marginally shorter for NE ( 4 weeks) than NY and OR birds ( $\sim 6$ weeks; Table 1$)$, but migration rate did not differ among sites (Table 1). Migration rate in the spring $(163 \pm 9.2 \mathrm{~km} / \mathrm{d})$ was $38 \%$ faster than in the fall $(t=3.77, \mathrm{df}=18, P=$ 0.001 ), and 2-way analysis of variance confirmed both the seasonal difference $(F=16.61, \mathrm{df}=1,16$, $P=0.001)$ and lack of a region effect $(F=2.50, \mathrm{df}$ $=2,16, P=0.113$ ). NE and OR birds exhibited both trans-GoM and terrestrial flights when confronted with the GoM, and comparison of fall and spring data for the 2 sites showed that transGoM flights tended to be more likely in spring (6 of 8 birds) than in fall ( 2 of 8 birds; Fisher exact 
test, $P=0.066$ ). Finally, the proportion of the annual cycle spent on the breeding grounds differed among sites (shortest in OR and longest in NE, Table 1), and averaged about a quarter of the year.

\section{South America}

Birds from NY (Fig. 2A, B, C) and the other locations entered South America in northwestern Colombia. OR birds settled and remained in the northwestern Amazon region of southern Colombia, northern Peru, and eastern Ecuador until the start of spring migration (Fig. 3A; minimum residence time $=160 \pm 3.6 \mathrm{~d}$ ), as did 1 bird from both NY (Fig. 2A, 3A) and NE (Fig. 3A). The 2 other birds from NY (Fig. 2B, C; Fig. 3B) and 5 birds from NE (Fig. 3B) continued moving south to stay initially in western Brazil and Bolivia (and probably Paraguay). Routes to this more southern first destination appeared to be largely through western Brazil (Fig. 2A, B). Mean residence time for NY and NE birds at the southern site was 136 $\pm 16.7 \mathrm{~d}(n=2)$ and $102 \pm 17.1$ days $(n=4)$, respectively. All NY and NE birds then relocated northwestward near the site where OR birds (and single NY and NE birds) spent the entire northern winter (Fig. 3B). NY and NE birds were in residence in southern Colombia, northern Peru, and eastern Ecuador for $29 \pm 15.0 \mathrm{SE} d$ and $60 \pm$ 5.7 SE d, respectively. Beginning around 9 February, latitude locations for OR and NE birds became unreliable, but most individuals converged on $74^{\circ} \mathrm{W}$ longitude moving north pre-equinox, and then south post-equinox. Four NE birds remained at that longitude, but their latitude fluctuated wildly until the initiation of spring migration. While these birds potentially moved north prior to spring migration, the north-south pattern of movement is consistent with shading error. One NY bird moved farther west to the coast of Ecuador (Fig. 2D), but then all NY birds began moving northward at the end of the first week of April, significantly earlier than NE and OR birds (Table 1). Except for the coastal NY bird, all kingbirds departed from the same general region in northwest Amazonia.

\section{Intra-individual variation}

Birds with 2 years of residency data in South America behaved similarly in both years. For
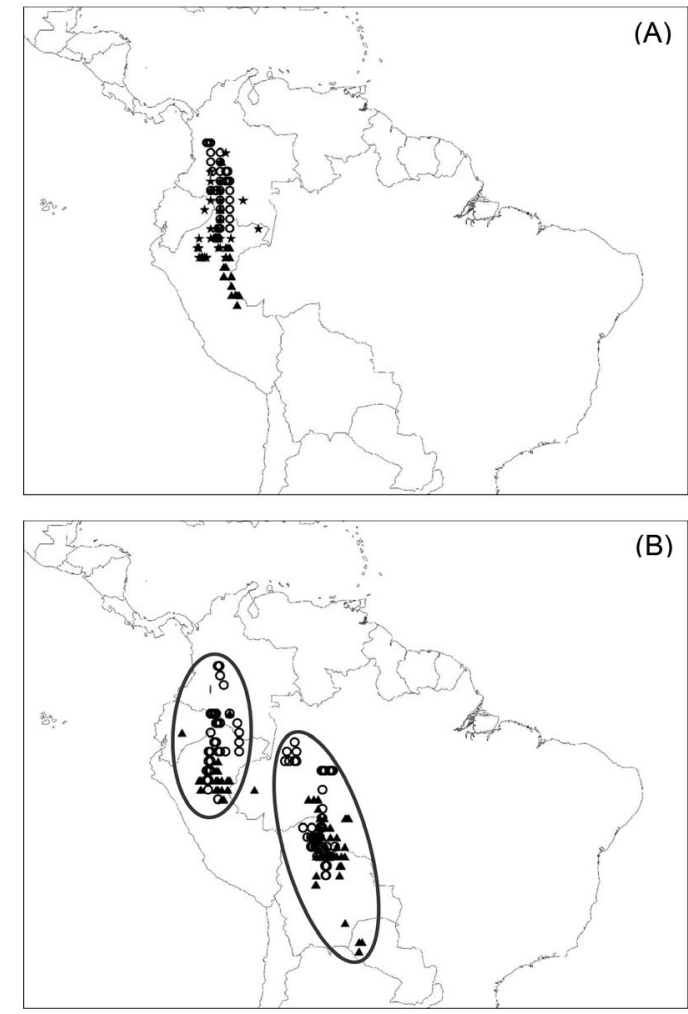

Figure 3. (A) Winter site for Eastern Kingbirds from New York (triangle), Nebraska (open circle), and Oregon (star) that remained in the northwestern Amazon basin throughout the entire nonbreeding season. All point estimates are from 1 November-1 February. Each point represents median latitude and longitude derived from Monte Carlo maximum likelihood estimates of a single bird for at least $1 \mathrm{~d}$, but possibly more than 30. (B) Wintering sites for Eastern Kingbirds from New York (triangle) and Nebraska (open circle) that exhibited intratropical migration. Eastern point estimates (to the right) enclosed by the ellipse are early nonbreeding season locations ( $\sim 1$ Nov-15 Jan) while points in the western part of the range (to the left) enclosed by the ellipse represent late winter locations after birds moved $(\sim 1$ Jan-1 Feb). The single point (triangle) between ellipses represents a bird in transit between early and late season locations. Point estimates past 1 February are not shown because several birds displayed shifts north, with all OR and NE birds showing strong shifts north prior to 21 March and south after 21 March while maintaining a stable longitudinal position due to the effects of shading on light levels.

instance, the single NE and single NY (Fig. 2A) individuals that remained in the northwest Amazon region of southern Colombia, northern Peru, and eastern Ecuador where the OR birds remained did so in both years, while the NY bird that flew farther south in the first year also did so in the 

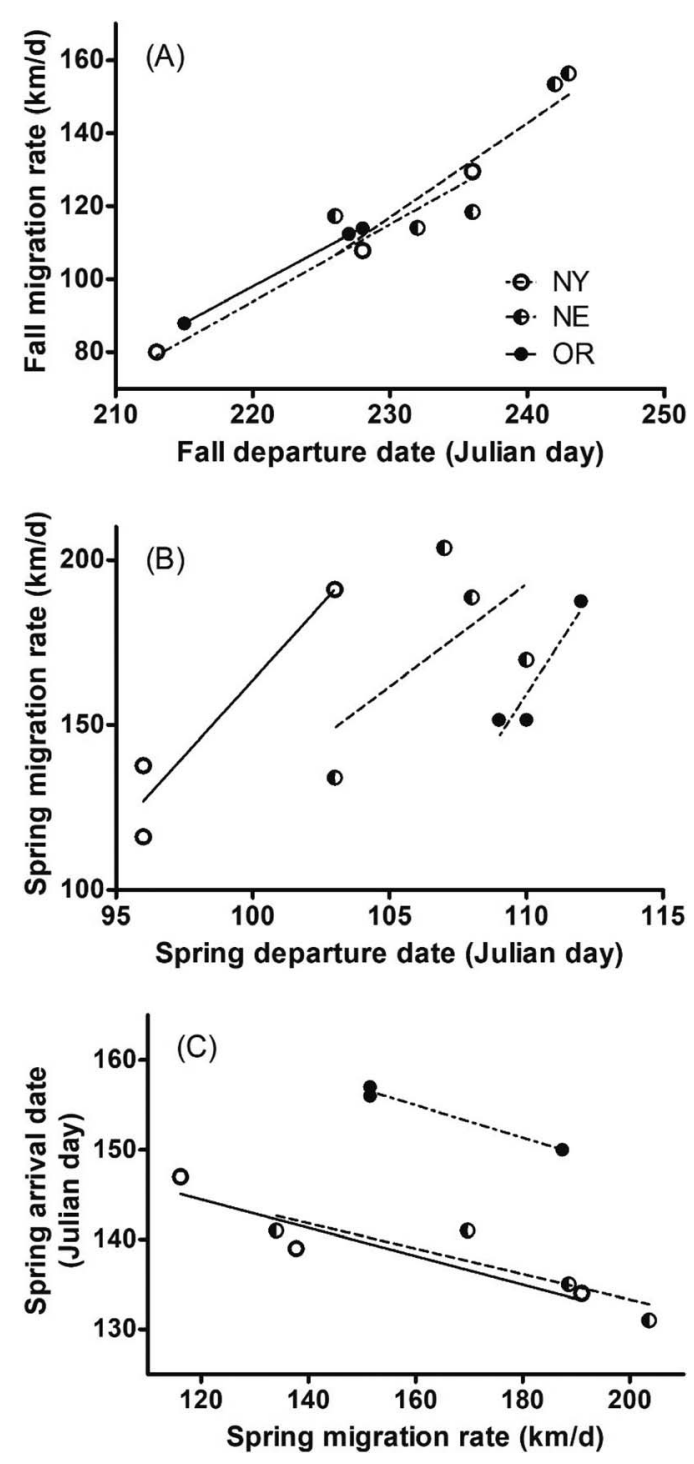

Figure 4. Relationships between Eastern Kingbird migration departure and arrival dates and migration rates for individuals from New York (open circle, solid line), Nebraska (half-filled circle, dashed line), and Oregon (filled circle and dotted/dashed line). Fall departure date and fall migration rate shown in (A), spring departure date and spring migration rate given in (B), while the relationship between spring migration rate and arrival on the breeding grounds is depicted in (C).

second, albeit by a different apparent route (Fig. 2B). Indeed, migratory paths at other stages also often differed between years. All NY birds departed from Florida, but the first bird with 2 years of data flew to Honduras in the first year, with a possible $1 \mathrm{~d}$ stop in Cuba, but flew nonstop to the Yucatan in the second (Fig. 2A). The second bird left from the Florida Keys in both years, stopped for $6 \mathrm{~d}$ in the Cayman Islands in the first year but in Cuba for $4 \mathrm{~d}$ in the second (Fig. 2B) before arriving in Honduras and Nicaragua in the first and second years, respectively. The NE kingbird with 2 years of data took a land route during fall of his first year but an overwater flight across the GoM in the following spring, but reversed those paths in his second year (for fall flights see Fig. 3).

\section{Associations among migratory behaviors}

Individual departure date from the breeding grounds ranged between 3 and 31 August, but birds with an early departure date did not arrive significantly earlier in South America $(r=-0.416$, $P=0.203, n=11)$. Birds appeared to compensate for late departure in the fall by migrating faster (Fig. 4A; $r=0.951, P<0.001)$ regardless of where they bred (ANCOVA: departure date, $F=$ 42.63, $\mathrm{df}=1,6, P<0.001$; region: $F=0.45, \mathrm{df}=$ $2,6, P=0.656)$. After omitting the NE kingbird that detoured to Georgia, birds with a late spring departure from South America exhibited a marginally nonsignificant tendency to migrate faster $(r$ $=0.604, P=0.065)$. However, departure date differed among sites (Table 1) and after accounting for site (ANCOVA: $F=3.48, \mathrm{df}=2,6, P=0.099$ ), late spring departure was indeed associated with faster migration (Fig. 4B; $F=11.37, \mathrm{df}=1,6, P=$ $0.015)$. Rapid spring migration was not associated with early spring arrival $(r=-0.472, P=0.169)$, but effects of migration rate may have been masked by the difference in arrival dates among regions (Table 1). Analysis of covariance to control for region $(F=53.83, P<0.001)$ confirmed that birds that migrated faster arrived earlier in spring $(F=30.72$, df $=1,6, P=0.002$; Fig. 4C).

\section{Discussion}

The Eastern Kingbird is an obligate intercontinental and facultative intratropical migrant with low levels of population connectivity that exhibits high variability in migratory behaviors both within and among populations, and to some extent, within individuals. Comparison of our reanalysis of the 
NE birds with that of Jahn et al. (2013a) yielded mostly similar results, but there were some differences. For instance, we found no indication that NE birds stopped in Cuba. Duration and rate of fall migration in the 2 analyses were virtually identical, but our duration of spring migration was longer, and correspondingly, migration rate was lower. It is uncertain why the latter differences exist, but we suggest that it is related to the difficulty of determining spring departure date from South America, but possibly also by differences in methods used to establish departure date. The ability to determine true departure date in late summer in the open habitats of North America where kingbirds breed is no doubt easier than in the forested habitats used by kingbirds while in South America where leaves and kingbird roosting behavior (R. Renfrew, pers. comm.) create problems of shading. The probable greater ease of establishing departure date in summer (because of better light conditions) likely explains the similar fall migration statistics, but poorer light conditions in South America likely introduced a bias in one of the two analyses. However, despite the difference in spring migration rate, Jahn et al.'s (2013a) conclusion that migration rate was higher in spring than fall was corroborated.

\section{Migratory routes}

Poor resolution of migratory paths for NE and OR birds, and small sample sizes overall, urge caution, but most fall migrants from NE and OR appeared to fly directly to the Gulf Coast, and from there, most reached Central America by taking a terrestrial route around the GoM. On the other hand, return spring flights from Central America by NE and OR birds were more often across the GoM, a seasonal pattern opposite of that shown by Tree Swallows (Tachycineta bicolor; Bradley et al. 2014). Eastern Kingbird data from eBird also suggest a land route along the east coast of Mexico is more common in fall than spring (PollackVelásquez et al. 2020). All NY kingbirds made trans-GoM flights in both seasons, but with some fall migrants stopping in Cuba or the Cayman Islands before reaching Central America.

Although routes of $\mathrm{NE}$ and OR kingbirds in North America were poorly resolved, birds from both populations appeared to be reverse-route migrants. NY kingbirds, by contrast, were loop migrants. All fall migrants made long-distance coastal flights to reach Florida, but spring migrants moved inland (Fig. 2D), a pattern confirmed by Pollack-Velásquez et al.'s (2020) eBird data. NY Eastern Kingbirds thus behave similarly to many eastern North American migrants by taking a more inland route in spring (La Sorte et al. 2014). Few studies have examined migration in a single species over an equally broad longitudinal range but fall migration of kingbirds was similar to that of Purple Martins (Fraser et al. 2012, 2013; Stutchbury et al. 2016). In both, migrants from far eastern portions of both species' ranges migrated through Florida, whereas populations located farther west either crossed the GoM in direct flights over the Gulf Coast or took a land route along the Mexican Gulf coastal plain. By contrast, all populations of Bobolinks from as far west as our OR study site departed from Florida to reach South America (Renfrew et al. 2013, 2019). In conformance with a majority of studies (McKinnon et al. 2013, Nilsson et al. 2013, Renfrew et al. 2019), kingbirds migrated faster in spring than in fall, and crossing the GoM in a nonstop flight in spring was a contributor.

\section{Population and individual variation}

Neither departure date nor arrival date in fall differed among populations, but departure date in spring from South America was delayed in OR birds compared to NY. In addition, OR birds arrived on their breeding grounds significantly later than birds from both NE and NY. OR kingbirds thus appeared to respond to the delayed spring phenology (compared to NE and NY) at their high-elevation breeding site by delaying their departure date rather than migrating at a slower speed (Table 1). Later arrival on the breeding grounds in OR was not matched by a later departure in fall, and thus length of time spent on the breeding grounds was shortest in OR. Regardless of location, birds that delayed departure in both fall and spring compensated by migrating faster (Fig. 4A, B). Indeed, the NE bird with 2 years of data appeared to take a land route along the Mexican Gulf coast to Central America in his first year but departed $\sim 2$ weeks later in fall of his second year (not included in statistics of Table 1) and crossed the GoM in a nonstop flight possibly in response to the late departure. Early 
arrival on the breeding grounds is associated with high seasonal reproductive success in kingbirds (Cooper et al. 2011), and thus selection for early arrival is likely strong. Rapid migration in spring resulted in earlier arrival on the breeding grounds in all populations (Fig. 4C) and more rapid migration is made possible by nonstop flights across the GoM. Thus, inexplicably, the NE kingbird with 2 years of data returned to NE by way of land in his second year (Fig. 1) and he arrived $10 \mathrm{~d}$ later than in his first year.

\section{Intratropical migration}

Intratropical migration by temperate migrants has been reported in the Neotropics and Afrotropics (reviewed by Stutchbury et al. 2016), but how widespread it is remains unknown. We corroborated Jahn et al.'s (2013a) description of ITM for kingbirds breeding in NE, and found that kingbirds breeding in NY, but not OR, behaved similarly; one individual from both NE and NY remained sedentary at the same northwest Amazon site used by OR birds, but others moved. ITM is thus not obligate in any of the populations we studied. The sedentary NE and NY birds were individuals with 2 years of data who behaved identically in both years, as did the other NY bird that exhibited ITM in both years. Sample sizes are small, but population differences in the propensity for ITM in kingbirds seems likely.

We cannot explain why ITM exists in kingbirds and other species, but avoidance of competition and exploitation of shifting resources are possibilities (Stutchbury et al. 2016). The competition avoidance hypothesis assumes costs of continued movement are outweighed by more access to resources at future destinations. But there must also be advantages to staying, and assuming reliability of resources, these include energy savings and knowledge of threats from predation, which may translate into greater survival and/or earlier return to breed. In fact, among the NE and NY birds, the 2 individuals that used only the single northwest Amazon site were the first individuals to be detected back on the breeding grounds, arriving $10 \mathrm{~d}(\mathrm{NE})$ and $9 \mathrm{~d}(\mathrm{NY})$ earlier than the average for others in their population that carried geolocators. Spring migration distance to $\mathrm{OR}$ is greater than to NE and NY, and we suggest that avoiding ITM to remain closer to spring departure points may be stronger for the OR birds that must migrate farther to reach their breeding grounds.

Eastern Kingbirds may also be predisposed to ITM because of their behavioral switch from breeding season territoriality and (mainly) insectivory to flocking and frugivory in the nonbreeding season (Morton 1971, Fitzpatrick 1980, Greenberg 1980). Fruit in the Neotropics is dependent on rain (Mendoza et al. 2017), and the wet season in the northwestern Amazon where the OR birds remained extends into early May (Jahn et al. 2013b). Fruit should be available throughout this period, but as noted above, competition may force many kingbirds to move. In the southwest Amazon, where most $\mathrm{NY}$ and NE birds spent most of their time in South America, rainfall begins to rise in November and then begins to decline from February to March (Jahn et al. 2010). Movement to the northwest, which is also seen in other kingbird species (MacPherson et al. 2018), places Eastern Kingbirds in a more productive environment later in the season that would also be closer to the departure point for spring migration. Individuals from all populations are thus in this same northwest Amazon region (southern Colombia, eastern Ecuador, western Brazil, and northern Peru) in late winter, making it an important staging area for kingbirds.

\section{Conclusion and the future}

Our coarse, but informative, description of continent-wide patterns of migration in Eastern Kingbirds leaves a number of unanswered questions. Apart from the obvious ones arising from small sample size, lack of cross-year comparisons, and need to better describe migration paths, all data were derived from males. We assume the sexes behave similarly (see Stutchbury et al. 2016 for an example), but it should be confirmed. Is the sedentary nature of the birds from the OR population replicable, and if so, is this restricted to birds from west of the Rocky Mountains? Intriguingly, the only population of Purple Martins to be highly connected and overwinter in regions distinct from all other martin populations was also from the Pacific Northwest (Stutchbury et al. 2016). Lastly, fruiting phenology for all regions within which Eastern Kingbirds overwinter in South America is very poorly known (Mendoza et 
al. 2017), as is the winter ecology of kingbirds (and most Nearctic-Neotropical migrants). We thus strongly encourage study of fruit resources, habitat use, and diet and foraging ecology of Eastern Kingbirds on their winter grounds because looming changes in precipitation arising from climate change may have large impacts on this largely unknown but major phase of the annual cycle.

\section{Acknowledgments}

We are grateful to the private landowners of New York who granted us access to the property, and to the staffs of Malheur National Wildlife Refuge and Platte River Whooping Crane Maintenance Trust for granting permission to conduct research at these protected sites. R.B. Renfrew gave technical assistance, N.W. Cooper provided a thorough review, and C.M. Chutter and S. Cancellieri were more than able-bodied field assistants in Oregon. A Faculty Enhancement Grant to MTM from Portland State University and National Science Foundation grant IOB-0539370 to MTM supported the research.

\section{Literature cited}

Bradley DW, Clark RG, Dunn PO, Laughlin AJ, Taylor CM, et al. 2014. Trans-Gulf of Mexico loop migration of Tree Swallows revealed by solar geolocation. Current Zoology. 60:653-659.

Cooper NW, Murphy MT, Redmond LJ, Dolan AC. 2011. Reproductive correlates of spring arrival date in the Eastern Kingbird Tyrannus tyrannus. Journal of Ornithology. 152:143-152.

[ESRI] Environmental Systems Research Institute. 2016. ArcGIS Desktop: Release 10.4.1. Redlands (CA).

Faaborg J, Holmes RT, Anders AA, Bildstein KL, Dugger $\mathrm{KM}$, et al. 2010. Conserving migratory landbirds in the New World: Do we know enough? Ecological Applications. 20:398-418.

Fitzpatrick JW. 1980. Wintering of North American tyrant flycatchers in the Neotropics. In: Keast A, Morton ES, editors. Migrant birds in the Neotropics: Ecology, behavior, distribution, and conservation. Washington (DC): Smithsonian Institution Press; p. 67-78.

Fraser KC, Stutchbury BJM, Silverio C, Kramer PM, Barrow J, et al. 2012. Continent-wide tracking to determine migratory connectivity and tropical habitat associations of a declining aerial insectivore. Proceedings of the Royal Society B. 279:4901-4906.

Fraser KC, Stutchbury BJM, Kramer P, Silverio C, Barrow $\mathrm{J}$, et al. 2013. Consistent range-wide pattern in fall migration strategy of Purple Martin (Progne subis), despite different migration routes at the Gulf of Mexico. Auk. 130:291-296.

Greenberg R. 1980. The abundance and seasonality of forest canopy birds in Barro Colorado Island, Panama. Biotropica. 13:241-251.
Hallworth MT, Sillett TS, Van Wilgenburg SL, Hobson KA, Marra PP. 2015. Migratory connectivity of a Neotropical migratory songbird revealed by archival light-level geolocators. Ecological Applications. 25:336-347.

Heckscher CM, Taylor SM, Fox JW, Afanasyev V. 2011. Veery (Cathrus fuscescens) wintering locations, migratory connectivity, and a revision of its winter range using geolocator technology. Auk. 128:531-542.

Hilty SL, Brown WL. 1986. A guide to the birds of Colombia. Princeton (NJ): Princeton University Press.

Jahn AE, Cueto VR, Fox JW, Husak MS, Kim DH, et al. 2013a. Migration timing and wintering areas of three species of flycatchers (Tyrannus) breeding in the Great Plains of North America. Auk. 130:247-257.

Jahn AE, Levey DJ, Mamani AM, Saldias M, Alcoba A, et al. 2010. Seasonal differences in rainfall, food availability, and the foraging behavior of Tropical Kingbirds in the southern Amazon Basin. Journal of Field Ornithology. 81:340-348.

Jahn AE, Levey DJ, Cueto VR, Pinto Lendezma J, Tuero DT, et al. 2013b. Long-distance bird migration within South America revealed by light-level geolocators. Auk. 130:223-229.

Koleĉek J, Hahn S, Emmenegger T, Procházka P. 2018. Intra-tropical movements as a beneficial strategy for Palearctic migratory birds. Royal Society Open Science. 5:171675. http://dx.doi.org/10.1098/rsos.171675

Kramer GR, Streby HM, Peterson SM, Lehman JA, Buehler DA, et al. 2017. Nonbreeding isolation and populationspecific migration patterns among three populations of Golden-winged Warblers. Condor. 119:108-121.

La Sorte FA, Fink D, Hochachka WM, Farnsworth A, Rodewald AD, et al. 2014. The role of atmospheric conditions in the seasonal dynamics of North American migration flyways. Journal of Biogeography. 41:16851696.

MacPherson MP, Jahn AE, Murphy MT, Kim DH, Cueto VR, et al. 2018 Follow the rain? Environmental drivers for Tyrannus across the New World. Auk. 135:881894.

McKinnon EA, Fraser KC, Stutchbury BJM. 2013. New discoveries in landbird migration using geolocators, and a flight plan for the future. Auk. 130:211-222.

Mendoza I, Peres CA, Morellato LEC. 2017. Continentalscale patterns and climate drivers of fruiting phenology: A quantitative Neotropical review. Global and Planetary Change. 148:227-241.

Morton ES. 1971. Food and migration habits of Eastern Kingbirds in Panama. Auk. 88:925-926.

Murphy MT. 2001. Habitat-specific demography of a longdistance, Neotropical migrant bird, the Eastern Kingbird. Ecology. 82:1304-1318.

Murphy MT, Pyle P. 2018. Eastern Kingbird (Tyrannus tyrannus), version 2.0. In: Rodewald PG, editor. Birds of North America. Ithaca (NY): Cornell Lab of Ornithology. https://birdsna.org/Species-Account/bna/ species/easkin

Nilsson C, Klaassen RHG, Alerstam T. 2013. Differences in speed and duration of bird migration between spring and autumn. American Naturalist. 181:837-845. 
Pollack-Velásquez LE, Ugaz A, Vallenos LM, Saldaña IS. 2020. The migratory records of the Eastern Kingbird (Tyrannus tyrannus) in the arid ecosystems of western South America. Ornithology Research. 28:143-150.

Rakhimberdiev E, Saveliev A, Piersma T, Karagicheva J. 2017. FLightR: An R package for reconstructing animal paths from solar geolocation loggers. Methods in Ecology and Evolution. 8:1482-1487.

Rakhimberdiev E, Winkler DW, Bridge E, Seavy NE, Sheldon D, et al. 2015. A hidden Markov model for reconstructing animal paths from solar geolocation loggers using templates for light intensity. Movement Ecology. 3:25. https://doi.org/10.1186/s40462-0150062-5

Rappole JH, Tipton AR. 1991. New harness design for attachment of radio transmitters to small passerines. Journal of Field Ornithology. 62:335-337.

R Core Team. 2017. R: A language and environment for statistical computing. Vienna (Austria): R Foundation for Statistical Computing. http://www.R-project.org/
Redmond LJ, Murphy MT. 2012. Using complementary approaches to estimate survival of juvenile and adult Eastern Kingbirds. Journal of Field Ornithology. 83:247-259.

Renfrew R, Kim D, Perlut N, Cadman M. 2019. Migration tactics of a long-distance migratory songbird from across a continental breeding range. Wilson Journal of Ornithology. 131:735-749.

Renfrew RB, Kim DH, Perlut N, Smith J, Fox J, Marra PP. 2013. Phenological matching across hemispheres in a long-distance migratory bird. Diversity and Distributions. 19:1008-1019.

Ryder TB, Fox JW, Marra PP. 2011. Estimating migratory connectivity of Gray Catbirds (Dumetella carolinensis) using geolocator and mark-recapture data. Auk. 128:448-453.

Stutchbury BJM, Siddiqui R, Applegate K, Hvenegaard GT, Mammenga P, et al. 2016. Ecological causes and consequences of intratropical migration in temperatebreeding migratory birds. American Naturalist. 188:S28-S40. 